\title{
Contributions from Literature for Understanding Wine Marketing
}

\author{
Vítor João Pereira Domingues Martinho
}

Citation: Martinho, V.J.P.D.

Contributions from Literature for Understanding Wine Marketing.

Sustainability 2021, 13, 7468.

https://doi.org/10.3390/su13137468

Academic Editor: Carlos

Rodríguez Monroy

Received: 8 June 2021

Accepted: 2 July 2021

Published: 4 July 2021

Publisher's Note: MDPI stays neutral with regard to jurisdictional claims in published maps and institutional affiliations.

Copyright: (C) 2021 by the author Licensee MDPI, Basel, Switzerland. This article is an open access article distributed under the terms and conditions of the Creative Commons Attribution (CC BY) license (https:/ / creativecommons.org/licenses/by/ $4.0 /)$.
Agricultural School (ESAV) and CERNAS-IPV Research Centre, Polytechnic Institute of Viseu (IPV), 3504-510 Viseu, Portugal; vdmartinho@esav.ipv.pt

Abstract: Marketing for wines is a determinant tool for several stakeholders within the wine sector, but there are not many studies concerning the topic "wine marketing" and even fewer that take a bibliometric approach. In turn, wine is a strategic agri-food product for the economy of several countries around the world, particularly in Mediterranean countries. Beyond the economic level, wine has an environmental, social, and cultural dimension. All these dimensions have implications in any plan for the wine sector and should be taken into account. In addition, these dimensions change around the world in accordance with different local factors. In this way, sometimes, it is not easy to design adjusted marketing plans for the wine sector, namely, in international markets. Taking the frameworks into account, the main objective of this study is to explore the scientific documents available on scientific platforms, namely, in the Web of Science, related to "wine marketing". These studies (87 documents) were first explored through bibliometric software, such as the VOSviewer and the Atlas.ti, and then analyzed individually to capture the main insights shown by the scientific literature about wine marketing. To better organize the literature survey, with the information obtained from the bibliometric analysis, the following indexes were identified through factor analysis: "supply index", "demand index", "winery strategy index", "tourism index", "innovation index", and "wine characteristics index". The supply index highlights questions related to new technologies, climate change, logistics in international markets, institutions and regulations, being the main factors that influence wine producers. The demand index stresses the relevance, for consumers, of the relationship between the price and quality of a wine. On the other hand, younger consumers, in general, consume wine outdoors while socializing, giving importance to the label, often when the wine is recommended by someone. Older consumers give greater importance to the wine's variety and to its region of origin. The winery strategy index shows the importance of questions relating to agri-chains, market differentiation, the history, and the brand. The tourism index brings together aspects associated with the complementarity between activities in the wine sector, wine routes, and contributions from culture and landscape. The innovation index highlights aspects related to the quality and the perceptions of the consumers. Finally, the wine characteristics index shows the little importance given by scientific literature relating to wine marketing and to attributes such as alcohol. A search on the Web of Science for the topic addressed here and "bibliometric" showed that there has been no research carried out with the approach taken here, showing the novelty of this study.

Keywords: agri-food strategies; bibliometric analysis; literature review; wine marketing; Mediterranean countries

\section{Introduction}

Wine marketing is a specific field within marketing strategies, having specific particularities. These specificities vary with the local characteristics of each wine region and with the particularities of each consumer or group of consumers. These frameworks hamper the design of efficient marketing strategies, more so when the international trade of wine has increased. In fact, a significant part of wine is consumed outside its country of origin. The Mediterranean countries, such as Spain, France, and Italy, are amongst the biggest players within the wine industry [1]. 
Another question concerns the gap that sometimes occurs between the producer's preferences, the sellers' strategies, and consumer objectives. Indeed, in some cases, the producer becomes too focused on the wine's characteristics (alcohol, acidity, etc.) and less on what the wine market wants. Some wine market segments give more importance to the taste and label, for example, than to the wine's features. A well-adjusted wine marketing plan should begin during production, where the producer has a determinant role in its success [2].

In this context, it is important to improve understanding and bring about more insights into wine marketing that is carried out around the world with benefits for all stakeholders, namely, for producers, sellers, policymakers, and marketers. There is plenty of scientific information produced by the international community about wine marketing that is important to explore and analyze further. For example, in the Web of Science's [3] main database, 2249 documents were found and, in the Scopus [4] database, 1182 studies were found (search performed on 26 November 2018). Nonetheless, these numbers reduced significantly when the two words (wine and marketing) were considered together ("wine marketing"), showing that there is still a great amount to be explored further in these domains. Taking into account these frameworks, this study aims to highlight the main insights from the literature about the topic "wine marketing".

\section{Material and Methods}

Taking this context into account, the main objective of this study is to explore the scientific literature available, namely, in the Web of Science [5], all databases, about wine marketing. Only the Web of Science platform was considered because of the framework of documents found. In fact, considering the expression "wine marketing" (with quotation marks), 87 studies were found on the Web of Science and 127 studies on the Scopus (where about 34 documents were repeated). These documents were examined through literature survey. However, to better perform this literature review, the several studies were first grouped via a bibliometric-factor approach, where the bibliometric analysis allows for obtaining relevant information about the different studies. This information was considered after factor analysis. The methodologies considered here follow the PRISMA approach [6] complemented by bibliometric analysis [7]. The wine sector and the systematic reviews have several dimensions [8-13], including the approaches with bibliometric analysis [14,15].

This research will be structured, after the introduction and this section for materials and methods, in five further sections. The next section will be to examine the $87 \mathrm{docu}$ ments through bibliometric approaches, namely, considering the VOSviewer [16] and the Atlas.ti [17] software. The fourth section is for the literature survey, individually analyzing each one of the studies found and related to wine marketing in the Web of Science. In the fifth section, the results obtained will be benchmarked with current data from experts and consumer opinions. The last sections will be for the main conclusions. Only documents published up to and including 2018 were considered (before the effect of the Covid-19 pandemic). Nonetheless, in Figures 1 and 2, the main terms of the studies published up to 2018 and during 2019 and 2020 will be considered for benchmarking. During 2019 and 2020, 21 further documents were published. 


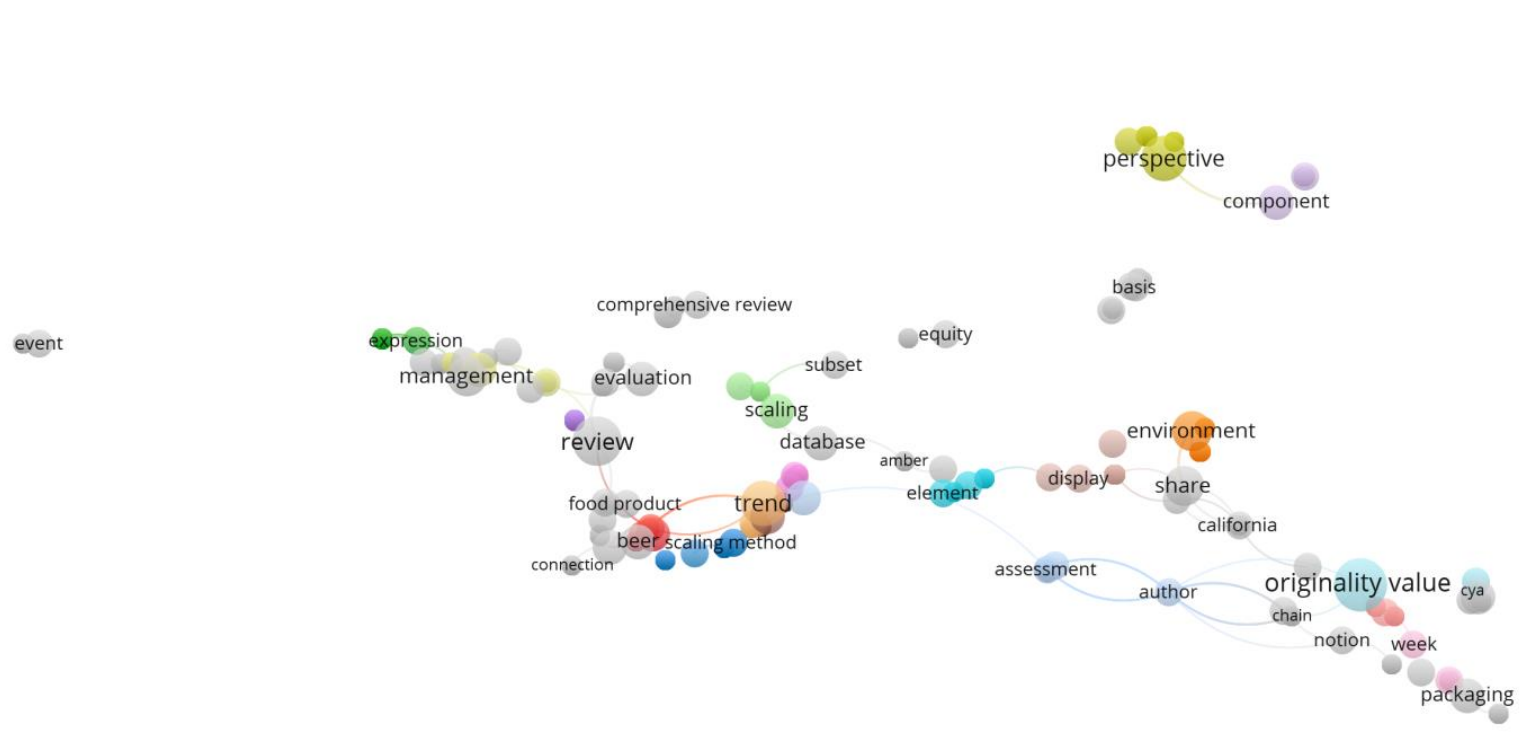

Figure 1. Network visualization map for the topic "wine marketing" up to and including 2018 and terms as items (considering 1 as minimum number of occurrences of a term and binary counting).

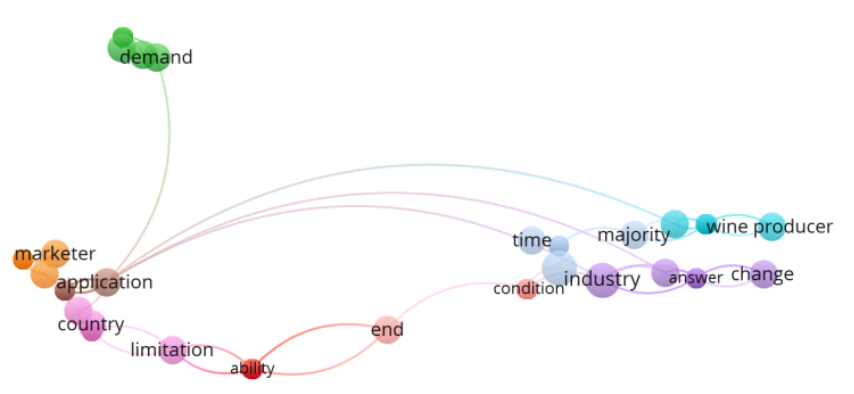

effect $O$ brand adaptation

Figure 2. Network visualization map for the topic "wine marketing" and the years 2019 and 2020 and terms as items (considering 1 as minimum number of occurrences of a term and binary counting).

In these figures the dimension of the circles and respective labels represent the number of occurrences (number of documents in which a term appears at least once) and the proximity of relatedness [18]. Up to 2018, the main terms (with higher occurrences) were, for example, "originality", "value", "trend", "environment", "management", and "share". In 2019 and 2020, the main items were "tourism", "brand", "change", "effect", and "experiential marketing". Since the new context created by the pandemic deserves special attention, the bibliometric analysis in this research will focus on studies up to 2018. In any case, the results obtained with bibliometric analysis will be benchmarked for the current context.

\section{Creating Indexes for Scientific Literature Relative to Wine Marketing}

In this section, indexes will be created for the scientific literature available in the Web of Science related to wine marketing. For this purpose, a word list was obtained from 80 documents found in the search that was carried out (for seven studies, the software was unable to import any document or abstract) through the Atlas.ti software. From this word list, the terms referred to the most in the documents were considered and analyzed through factor analysis, taking into account the Stata [19] and Torres-Reyna [20] procedures. Table A1 (Appendix A) summarizes the word list (for the terms that were referred to the most in the documents) by study (for each study the name of the first author, year of publication, and the title are shown). The word list is based on information that was possible to import by the software for each study. This research follows studies such as those, for example, developed by Martinho [14,15]. 
The words most referred to in the 80 documents are as follows (Table A1): alcohol, brand, California, companies, consumer, consumption, generation, industry, market, marketing, new, Portugal, price, product, production, quality, research, social, study, tourism, value, wine, and wineries. This list of words shows the importance of questions related to, for example, the brand, generations, price, quality, and tourism for wine marketing. Innovation and the research also play a determinant role here, as well as the social and cultural dimensions. The several options related to production and transformation also have their importance in any wine marketing plan. Despite the significance of Spain, France, and Italy in the world of wine, they do not appear among the main words, which seems to imply that the old-world wine does not attract as much attention (at least to be explicitly referred) as new world wine or that of a small country, such as Portugal.

\subsection{Factor Analysis for the Words List}

The factor analysis will make it possible to create indexes (factors), reducing the number of variables (in this case, words), and allow for the exploration of relationships between the several words considered. Table 1 shows the results obtained through principal factors $[19,20]$ with rotation (orthogonal varimax). Table 1 demonstrates that a large portion of the words are related to the first six indexes (with variance superior than 1 and a cumulative of 0.951 ). In general, only the indexes with variances greater than 1 should be considered in factor analysis [20]; because of this, the explanations in Table 1 will focus only on the indexes 1 to 6 and will ignore indexes 7 to 13. In fact, indexes 1 to 6 explain $95.1 \%$ of the total variance. The results in Table 2 support these options, because the higher correlations of the several variables are for indexes 1 to 6 .

Table 1. Indexes obtained through factor analysis/correlation.

\begin{tabular}{lcccc}
\hline & Variance & Difference & Proportion & Cumulative \\
\hline Index1 & 5.967 & 0.297 & 0.308 & 0.308 \\
Index2 & 5.670 & 3.531 & 0.293 & 0.601 \\
Index3 & 2.139 & 0.018 & 0.111 & 0.712 \\
Index4 & 2.121 & 0.776 & 0.110 & 0.821 \\
Index5 & 1.345 & 0.169 & 0.070 & 0.891 \\
Index6 & 1.177 & 0.454 & 0.061 & 0.951 \\
Index7 & 0.722 & 0.543 & 0.037 & 0.989 \\
Index8 & 0.179 & 0.076 & 0.009 & 0.998 \\
Index9 & 0.103 & 0.047 & 0.005 & 1.003 \\
Index10 & 0.047 & 0.003 & 1.006 \\
Index11 & 0.057 & 0.003 & 0.001 & 1.007 \\
Index12 & 0.010 & 0.005 & 0.000 & 1.007 \\
Index13 & 0.007 & & 0.000 & 1.007 \\
\hline
\end{tabular}

In Table 2 (rotated factor loadings and unique variances), the relationships between each word and the several indexes are shown (California and Portugal were dropped because of zero variance).

Index 1 is mostly defined by companies, industry, market, marketing, production, and research. This is an index (supply index) that relates to the importance of several dimensions from the production and transformation side of wine marketing.

For index2, words such as consumer, consumption, generation, product, social, value, and wine have more relevance. In this way, index 2 seems to be more of a demand index. Index3 is, namely, defined by the price and wineries (winery strategy index). In turn, index4 is better explained through the word tourism (tourism index), index 5 more so through new and quality (innovation index), and index 6 through alcohol (wine characteristics index).

Considering the factor analysis made earlier, it was possible to identify, from the scientific literature available in the Web of Science, relative to "wine marketing", the following six indexes: "supply index", "demand index", "winery strategy index", "tourism index", "innovation index" and "wine characteristics index". These six indexes highlight 
the determinant role for wine marketing of the main stakeholders in the wine market (namely, the producers/sellers and the consumers), as well as the contributions from wine tourism, innovation/quality, and wine characteristics. Note the poor relevance of the word "brand" in the definitions of the various indexes and the higher uniqueness. This is a surprising result considering the importance of the brand in the marketing-mix. Consumers seem to give greater importance to the label and the region of origin, for example, and less to the brand itself. In any case, brand equity does hold some importance for luxury wines.

Table 2. Relevance of each variable (word) within the respective indexes.

\begin{tabular}{|c|c|c|c|c|c|c|c|c|c|c|c|c|c|c|}
\hline & Index1 & Index2 & Index 3 & Index4 & Index 5 & Index 6 & Index7 & Index8 & Index9 & Index10 & Index11 & Index12 & Index13 & Uniqueness \\
\hline alcohol & 0.091 & 0.020 & -0.026 & -0.013 & -0.024 & 0.965 & -0.007 & -0.006 & 0.000 & 0.001 & 0.001 & 0.000 & 0.000 & 0.059 \\
\hline brand & 0.205 & 0.270 & 0.101 & 0.365 & 0.137 & -0.061 & -0.010 & 0.386 & 0.003 & -0.001 & 0.000 & 0.000 & 0.000 & 0.570 \\
\hline companies & 0.977 & 0.005 & 0.028 & -0.081 & 0.146 & -0.104 & 0.008 & 0.041 & -0.011 & 0.031 & -0.017 & -0.001 & 0.000 & 0.004 \\
\hline consumer & 0.096 & 0.677 & 0.337 & 0.014 & 0.126 & -0.017 & 0.601 & -0.013 & 0.009 & 0.014 & -0.007 & 0.003 & -0.002 & 0.041 \\
\hline consumption & 0.174 & 0.885 & 0.257 & 0.110 & 0.011 & 0.229 & 0.196 & 0.006 & 0.052 & 0.023 & -0.004 & 0.035 & 0.003 & 0.013 \\
\hline generation & -0.037 & 0.960 & -0.011 & -0.053 & 0.005 & -0.039 & -0.027 & -0.016 & -0.026 & -0.028 & 0.005 & -0.031 & -0.017 & 0.070 \\
\hline industry & 0.883 & 0.056 & 0.231 & -0.126 & 0.092 & 0.322 & -0.104 & -0.025 & 0.010 & -0.010 & -0.046 & -0.001 & 0.011 & 0.022 \\
\hline market & 0.777 & 0.334 & 0.217 & 0.215 & 0.255 & -0.095 & 0.152 & 0.005 & 0.069 & -0.065 & 0.053 & 0.008 & 0.005 & 0.083 \\
\hline marketing & 0.926 & 0.107 & 0.100 & 0.241 & 0.014 & 0.219 & 0.061 & 0.023 & 0.010 & -0.002 & 0.023 & -0.034 & -0.006 & 0.008 \\
\hline new & 0.617 & 0.104 & 0.139 & 0.265 & 0.681 & -0.021 & 0.040 & -0.056 & -0.036 & -0.037 & 0.025 & 0.011 & -0.002 & 0.048 \\
\hline price & 0.304 & 0.224 & 0.848 & -0.106 & 0.242 & 0.000 & 0.190 & 0.014 & 0.045 & 0.024 & -0.004 & -0.009 & -0.002 & 0.030 \\
\hline product & 0.546 & 0.681 & 0.140 & -0.120 & 0.186 & -0.072 & 0.369 & 0.055 & -0.013 & -0.049 & 0.042 & -0.018 & 0.007 & 0.020 \\
\hline production & 0.852 & 0.057 & 0.394 & 0.232 & 0.186 & -0.062 & 0.003 & -0.003 & -0.004 & -0.030 & 0.014 & 0.046 & -0.004 & 0.019 \\
\hline quality & 0.309 & 0.571 & 0.157 & 0.232 & 0.674 & -0.032 & 0.087 & 0.097 & 0.034 & 0.038 & -0.026 & -0.011 & 0.002 & 0.024 \\
\hline research & 0.747 & 0.484 & 0.093 & 0.332 & -0.061 & -0.051 & 0.181 & 0.078 & -0.019 & 0.099 & -0.015 & 0.005 & -0.004 & 0.033 \\
\hline social & -0.037 & 0.797 & -0.031 & 0.124 & 0.092 & -0.004 & -0.046 & -0.011 & -0.244 & -0.020 & 0.000 & -0.001 & 0.000 & 0.277 \\
\hline study & 0.566 & 0.542 & 0.091 & 0.477 & 0.007 & 0.012 & 0.204 & -0.019 & 0.088 & 0.168 & 0.000 & -0.001 & 0.001 & 0.072 \\
\hline tourism & 0.118 & 0.035 & 0.076 & 0.950 & 0.211 & -0.009 & -0.003 & 0.020 & 0.002 & -0.005 & 0.000 & -0.001 & -0.002 & 0.032 \\
\hline value & 0.189 & 0.945 & 0.047 & 0.036 & 0.168 & -0.050 & -0.031 & 0.064 & 0.088 & 0.020 & -0.001 & 0.012 & 0.017 & 0.024 \\
\hline wine & 0.287 & 0.630 & 0.587 & 0.317 & 0.208 & -0.018 & 0.113 & 0.007 & 0.071 & 0.040 & -0.016 & -0.010 & -0.020 & 0.012 \\
\hline wineries & 0.278 & -0.003 & 0.728 & 0.535 & -0.204 & -0.024 & -0.109 & 0.010 & -0.098 & -0.051 & 0.014 & 0.016 & 0.013 & 0.040 \\
\hline
\end{tabular}

Finally, Table 3, with the results for Kaiser-Meyer-Olkin's measure of sampling adequacy, demonstrates a good overall KMO of 0.834 (Filho and Júnior [21], for example, consider 0.5 as an acceptable minimum), confirming the adequacy of the sampling. For KMO results interpretation, Hair et al. [22] is also suggested. The variable with the worst KMO (below the minimum acceptable, considering that referred to by the related literature) is the word alcohol; however, it was maintained in order to highlight its lack of importance in wine marketing.

Table 3. Results for Kaiser-Meyer-Olkin measure of sampling adequacy.

\begin{tabular}{ccc}
\hline & KMO \\
\hline alcohol & 0.147 \\
brand & 0.856 \\
companies & 0.747 \\
consumer & 0.810 \\
consumption & 0.880 \\
generation & 0.860 \\
industry & market & 0.854 \\
marketing & 0.972 \\
new & 0.840 \\
price & 0.868 \\
product & 0.740 \\
production & 0.866 \\
quality & 0.909 \\
research & 0.819 \\
social & 0.925 \\
study & 0.856 \\
tourism & 0.924 \\
value & 0.559 \\
wine & 0.827 \\
wineries & 0.887 \\
Overall & 0.628 \\
\hline
\end{tabular}

In the next subsection, groups of studies will be created considering these six indexes, so as to improve the literature review. 


\subsection{Grouping Several Documents with the Indexes Found Through Factor Analysis}

In this subsection, the 80 documents obtained from the Web of Science will be grouped into six sets. For this purpose, in the first step, a calculation for the ratio of the number of times a word appeared in a document relative to the total number of times that word appeared in the total number of studies was performed. In a second phase, the index where each document displayed the higher ratio was then identified. The results are those shown in Table A2 (Appendix A).

The "supply index" and "demand index" are the indexes with more documents, as expected, considering the number of words associated with these two factors. On the other hand, the "wine characteristics index" relative to the word "alcohol" has the least number of studies associated, revealing the insignificance or little importance of these aspects in wine marketing.

\section{Literature Analysis}

In this section the several documents explored earlier will be analyzed further and grouped into six sets, taking into account the six indexes identified through factor analysis. One subsection for the documents related with each individual index will be shown.

\subsection{Supply Index}

Wine marketing promoted by several stakeholders will face several challenges in the future. The education of consumers will play a decisive role in wine strategies promoted by producers and sellers [23]. New technologies in communication are also a big challenge, namely, for the small- and medium-sized wine producers; nevertheless, they have come to stay and provide new opportunities [24-28]. Targeting markets with precision and exploring new opportunities is essential for success [29]. Climate change and global warming are other factors that will require adjusted approaches, namely, those related to the changes in the characteristics of the terroir [30].

In these contexts, decisions related to production alternatives, namely, those associated with sustainability and the environment, have their influence on several options available for stakeholders in terms of marketing strategies [31,32]. This question holds greater significance in international wine markets, where the competition is stronger [33,34]. In any case, the diversification in international markets may provide an interesting approach in terms of wine marketing [35].

In the relationships between wine producers/sellers and buyers, brokers, namely, for French wine, may provide interesting contributions as intermediaries, specifically if the producers/sellers are not part of collective organizations with the right conditions for supporting wine commercialization [36]. The collective strategies, namely, for international markets, may be an interesting approach, specifically for small producers [37]. Some countries, such as, for example, Lithuania, play important roles in international markets as trade platforms for some specific markets, such as the Russian one [38].

The relationships between the many stakeholders who operate in the wine markets are dynamic. The producers/sellers as a part of these frameworks need to have adjusted strategies for each market and its particularities. For example, the Greek cask wine market shows evidence of being divided into several segments, such as the knowledgeable, convenience searchers, experienced, and risk averse. On the other hand, the behavior of these segments changes with past experiences and with the importance given to intrinsic and extrinsic wine characteristics [39]. In addition, sometimes the old-world wine countries are product oriented, whereas the new-world has more of a market orientation [40].

Government regulations implemented around the world are another area many stakeholders should take into account when designing any wine marketing plan [41]. Wine marketing provides a crucial contribution to the dynamics and performance of the sector around the world; however, its design is affected by several factors [42-45], where scientific research brings fundamental insights [46-48]. In any case, the social and cultural dimension of the wine should also be considered and explored within wine marketing plans [49,50]. 
Multisensory tendencies are another aspect to be taken into account when considering the several dimensions of wine in societies [51].

\subsection{Demand Index}

There are new tendencies in wine consumption, where the influence of friends has its importance, as well as sensory characteristics and health concerns [52]. The sensory aspects were also highlighted by Marques and Guia [53], and satisfaction was stressed by some studies [54]. In any case, the relationship of price/quality continues to have great relevance, more than, in some cases, that of the wine's origin; however, this last question also depends on the origin of the consumers [55]. The brand seems to be of lesser importance in wine marketing, specifically on social media [56].

The behavior of consumers in wine consumption presents significant differences between generations $[57,58]$. The young generations are specific markets with specific characteristics where it is important to adopt adjusted strategies, namely, improving the perceptions about the wine in question, communication, packaging design, and the decision process [59,60]. In fact, millennials, for example, tend to consume alcoholic beverages outside the home when socializing with friends and family, for special occasions [61], enjoying wines that have a good taste where the percentage of alcohol is not so important [62]. In turn, Chinese younger adults have little knowledge about wine; drink less frequently; prefer red wines; tend to drink at home, hotels, and restaurants; and drink for social communication [63]. The older generation give greater importance to the grape variety and the written information, showing more knowledge, involvement, and experience with wine [64] and being less concerned with sustainability [65]. These are important insights for wine marketing that may bring important contributions towards increasing wine consumption around the world [66], where personal recommendations hold more and more relevance [67]. In these contexts, social media can contribute to a more effective understanding about the consumers' needs and preferences [68,69]. In any case, market understanding is crucial for any efficient marketing plan [70-75].

Sometimes, it is important to analyze history to better understand and plan the present, and this is also true for the wine sector [76], namely, when the intention is to create value and implement innovations in any part of the process from production to its final consumption $[77,78]$. In some cases, history is an important means of positioning and differentiation [79].

\subsection{Winery Strategy Index}

The majority of wine production in the United States is concentrated in wineries from a small number of states. Some of these wineries, namely, the smaller ones, adopt the strategy of selling the wine directly to the final consumers in the winery, improving revenues [80]. In 2006, about $90 \%$ of the value of United States wine production was concentrated in California [81].

Another question that concerns wineries and their strategy is the relationship between the brand and the prices. The reality shows that there is brand equity in luxury wines [82], showing that, in some cases, the aspects related to brands often matter [83] and can be considered for differentiation [84]. In any case, the effects from the brand on wine consumption depend on several factors [85]. The perceptions about the quality of the wine play relevant roles in the decision processes of consumers [86], which, in conjunction with the prices, may make all the difference at the time of purchase [87].

In some cases, and for some markets, history and the territorial characteristics should be considered in the strategies implemented by the wineries [88]. In fact, sometimes, organic attributes seem to be more important than, for example, the color, albeit less relevant than the price and the country of origin [89]. Digital wine marketing and social media marketing are important tools that should be considered in the strategies adopted by wineries [90]. 


\subsection{Tourism Index}

Wine tourism is an interesting way to improve the income of the wine producers as a complementary activity to wine production $[91,92]$. This complementary activity may have an additional importance, namely, in smaller wineries, where all sources of revenues have an influence on the dynamics and performance of the wine producers.

The history and the landscape of the wine regions are also decisive for an effective and successful wine tourism strategy [93]. Wine routes, being well organized and promoted, have an important role to play in any integrated wine tourism strategy, both in old-world wine and new-world wine countries.

The brand's personality seems to be another important strategy for wine tourism, namely, in the realms of excitement and sincerity. In general, this is a strategy more adopted by countries such as Australia, New Zealand, and South Africa, than by regions such as Bordeaux or Napa [94].

\subsection{Innovation Index}

Making something new is the aim of a large part of firms around the globe, namely, to reduce the competition and to obtain more revenue. It is possible to implement innovation in any part of the process, from production to the final consumer. The process of wine production involves several steps, some of which have their own complexity [95]. Sometimes it is simple, other times it requires scientific research. This is true for any socioeconomic sector, as well as for wine production, where questions related to, for example, tasting minerality appear to assume new relevance [96] and may be an interesting source for finding innovative ideas.

In any case, quality has its influence on the decision process of buying [97] and, as a consequence, this wine attribute should be taken into consideration in the innovation of developments. The differences in levels of quality should be considered for wine differentiation and positioning in the market place [98]. The perception of quality attributes may also reduce the concerns of consumers with regard to controversial products, such as genetically modified wine [99]. However, the perceptions of quality are not equal for all age and gender groups [100]. This means that to put any innovation into practice it is crucial to understand the preferences of the potential consumers. In any case, the quality of a wine, as with other attributes, depends on several factors, some of which are difficult to control [101].

\subsection{Wine Characteristics Index}

There is only one document [102] related to this index where the word that appears the most is the term "alcohol", having a weight of $88 \%$ (Table A2 in Appendix A). This seems to show that when dealing with wine attributes, namely, those related to alcohol, they simply are not important enough to appear in wine marketing.

In fact, it is a wine's quality that is important for wine marketing, but more so in dimensions related to the taste, color, and region/country of origin. In these contexts, it is important to stress that in some wine purchasing decisions, more relevance is given to the perceptions about quality than quality itself.

\section{Benchmarking the Results with Current Opinions from Consumers, Trade, and Experts}

The results obtained before are now benchmarked with the information provided by "Wine Opinions" [103]. Wine Opinions is a leader in US wine market research for several stakeholders, considering the opinions from consumers, trade, and experts. Table 4 shows the information published by Wine Opinion through monthly newsletters since November 2019. 
Table 4. Current opinions about the wine world from consumers, trade, and experts.

\begin{tabular}{cc}
\hline Months & Opinions \\
\hline November 2019 [104] & After 20 years of acquisition share, the wine market is now in line with the other alcohol beverages.
\end{tabular}

December 2019 [105] A large portion of iGen (21-24) and millennial (25-29) prefers sparkling wine fairly or a little sweet (54 and 46\%, respectively). Millennial (30-39), GenX (43-54), and boomer (55-73) prefer sparkling wine somewhat or very dry (50, 66 , and $76 \%$, respectively).

The main factors that influence the wine purchase are: country or region; tasting in the store; advice

January 2020 [106] from expert family member or friend; recommendation from staff in store; positive review; high score; with $10 \%$ discount or more; recommendation on a wine app; a special display that gets attention. The cheaper bottles of wine (under 19.99 US dollars) are bought weekly or monthly and the expensive ones (30 US dollars or more) are bought several times a year or less often.

Millennial (26-43), GenX (44-55) and boomer (56-74) are the generations with higher frequency

February 2020 [107] wine consumption.

If the European wine prices increased, the majority will buy their favourite wine but less often or from non-European regions.

Canned wine increased last year significantly.

March 2020 [108]

California, Oregon, Washington, South Africa, Chile, Argentina, Australia, and New Zealand are alternatives for more expensive (because tariffs) European wine.

Wine drinkers prefer Facebook and Instagram, relatively to Twitter, to follow wine accounts. The generation between 30 and 42 is that more use social media.

Sales increased in dollars in March weeks comparatively to homologous weeks.

April 2020 [109]

Special Edition Newsletter-Say Goodbye to Gen Z [110]

May 2020 [111]

Special Edition Newsletter-Discussion Groups [112]

June 2020 [113]

July 2020 [114]

August 2020 [115]

A relevant portion considers the European wines more expensive but better than the domestic wines. GenZ buys white, rosé, and sparkling wines. The bottles bought weekly are in the 10-15 dollars price range. This generation buys canned wines.

Wine drinkers are a small part of the all legal drinking age people and an even smaller section drink wine more often than once a week.

As everything with the pandemic, a part of the wine tasting and discussion becomes online.

Rosé sales increased significantly over the last years.

Wine sales online increased significantly within the pandemic context.

The wine consumption appears to be one of the alternatives to enjoy the holidays at home with lockdown.

New purchases are mainly from Oregon, France, Chile, Argentina, and Australia. In 2019 , only $11 \%$ of US wine drinkers bought bag-in-box monthly or weekly.

September 2020 [116]

In a recent survey, the majority of the women prefer bargain bottles and the men buy mainly bottles costing 20 dollars or more.

Reasons to drink wine: tradition; alcohol effect; symbol of sophistication; taste of wine; social reasons. The majority of the customers consider that the ingredient labelling has no effect on the purchase intent.

November 2020 [118]

December 2020 [119]

A significant number plan to drink wine with family or friends on a Zoom chat or buy special wines for holidays; give wine to more people; spend more per bottle on gift wine.

January 2021 [120]

February 2021 [121]

March 2021 [122]

April 2021 [123]

May 2021 [124]

The great majority of high frequency wine drinkers do not expect any change in the beverage alcohol habits.

The great majority of the consumers have the same financial conditions in the end of 2020 as they had a year ago and a great number expect to have the same at the end of 2021.

In US, the wine tourists belong to wine clubs.

The wine trade employment remains, in general, stable.

In the last 12 months, the wine trade consumption frequency increased more than spirits and beer. A great increase in the hard seltzer market share is expected.

The opinions of consumers, trade, and experts highlight the importance of wine within alcoholic beverages and the importance of age and gender for market segmentation. These opinions also show the relevance of the following dimensions: opinions of family and friends; prices; social media; regions of wine origin; wine tourism; new trends, such as hard seltzers; and new packaging, such as canned wine. In turn, the pandemic context changed the paradigms by increasing wine consumption in some circumstances and creating new ways to socialize whilst drinking wine (Zoom chats). Finally, this information reveals that ingredient labelling has no influence on the buying decision.

These current opinions from consumers, stakeholders, and experts are in line with the findings obtained through the bibliometric analysis and literature review, stressing the significance of the results shown here. 


\section{Main Insights}

The research performed here highlights that wine marketing plans should focus, mainly, on the following aspects: market analysis (internal and external); segmentation and marketing-mix (product, price, place, and promotion). In the wine market, characterization is important for understanding the producers/sellers (internal analysis) and to describe current/potential consumers (external analysis). For segmentation, the identification of the main criteria with which to segment consumers in the market has its relevance in a wine marketing strategy. Relative to the marketing-mix, the description of several dimensions from the four policies plays a crucial role in these frameworks.

When it comes to the internal analysis, it is crucial to identify the main characteristics of the producers/sellers, namely, in terms of skills, in order to apply new technologies and deal with climate change and global warming. Another question is relative to the strategies of wine producers/sellers in international markets, because these markets are the future for the wine sector, but these markets are usually more competitive and need more adjusted approaches, namely, those related to diversification and sustainability (organic farming). Finally, it is important to characterize the contexts in which the producers/sellers operate, specifically those related to their institutional framework, policies, and legal instruments.

Relative to the external analysis it is crucial to characterize the behavior and identify the preferences and perceptions of both current and potential consumers, namely, in terms of influencing friends, sensory characteristics, and the search for satisfaction by consumers in wine consumption.

For segmentation, the main criterion seems to be age, since the behavior in wine consumption often changes across generations. For example, millennials tend to drink with friends and family and on special occasions. They give more relevance to external and current (concerns with the environment and sustainability) attributes. The older generation places more importance on written opinions and the intrinsic characteristics.

In the product policy from the marketing-mix, the main focus should be more on innovation and less on wine attributes, such as the alcohol content. The wine production process has complex phases where innovation may bring interesting insights into improving chains from producers to the end consumer. Innovation must be considered in order to improve wine quality considering its importance in the decision process for buying and may also be considered for wine differentiation and positioning. With wine attributes, more attention should be paid to dimensions associated with taste and color, for example, and less to others like alcohol. Brand equity exists, namely, for luxury wines.

Concerning a pricing policy, the price/quality relationship maintains its importance. Prices, the quality of the wine, and in some cases, health concerns and the environment seem to be among the main factors that influence wine consumption. The terroir, in certain circumstances, and new technologies for information and communication also have their influence on the wine consumer.

In terms of placement policy, the short agri-food chains and winery events are new tendencies. Selling directly to end consumers in wineries is an interesting strategy, specifically for smaller producers. Another question is wine production clustering in certain parts of the world. For example, the majority of wineries in the United States are concentrated around a reduced number of states, and a significant number are in California.

The promotion policy is also a crucial approach from the marketing-mix and it is here where it sometimes may prove itself to be interesting in promoting wine together with other products and services, such as wine tourism and wine routes. Wine tourism is a complementary activity that provides the opportunity for wine producers to obtain more income, namely, for smaller wineries where the profit margins are smaller. The history and the landscape of wine regions, as well as wine routes, make important contributions to successful wine tourism strategies. Communication, namely, through modern means of information, also plays an important role here. 
These are relevant insights for world wine countries and their respective stakeholders (entrepreneurs, marketing operators, farmers, and wineries), namely, for the bigger wine players, such as the Mediterranean countries, where Spain, France, and Italy are known for being some of the biggest wine producers and where the wine sector has a relevant multiplier effect on their respective economic dynamics, in addition to its direct socioeconomic and cultural impact.

\section{Conclusions, Limitations, and Suggestions for Future Studies}

The research carried out here highlights that there are still many fields to be explored in the domains of "wine marketing". This topic does not motivate many studies comparative to other issues, maybe due to its complexity. In fact, wine marketing involves several dimensions and multiple particularities that change across countries and regions. In any case, wine has diverse dimensions from the economic to the religious, including environmental, social, and cultural domains, and because of this, it deserves special attention from different stakeholders, including the scientific community.

Age and gender are the main criteria to be considered for market segmentation. In fact, the behavior of different generations and genders within the wine markets are different, and this must be considered in marketing plans. On the other hand, price, quality, and region of origin are variables that also influence the pattern of wine consumption.

The research presented here follows an approach based on a factor analysis for the more relevant terms, considering, for example, the research of Martinho [15]. Nonetheless, to benchmark it could be interesting so as to consider other approaches in future research.

There are some gaps in the literature that should be addressed in future studies, namely, those related to the relative lack of documents produced concerning the relevance of wine characteristics for wine marketing. In fact, the consumers give less importance to these wine specificities, but this could be better addressed by the literature. In addition, the wine sector follows a trend of diversification in contrast with the suggestions from marketing experts, who suggest specialization and more focus.

Funding: This work is funded by National Funds through the FCT - Foundation for Science and Technology, I.P., within the scope of the project $\operatorname{Ref}^{\mathrm{a}}$ UIDB/00681/2020. Furthermore we would like to thank the CERNAS Research Centre and the Polytechnic Institute of Viseu for their support.

Institutional Review Board Statement: Not applicable.

Informed Consent Statement: Not applicable.

Data Availability Statement: The data that support the findings of this study are available from the author upon reasonable request.

Conflicts of Interest: The author declares no conflict of interest. 


\section{Appendix A}

Table A1. Words list for the terms most referred to in scientific documents, available on the Web of Science, related to wine marketing.

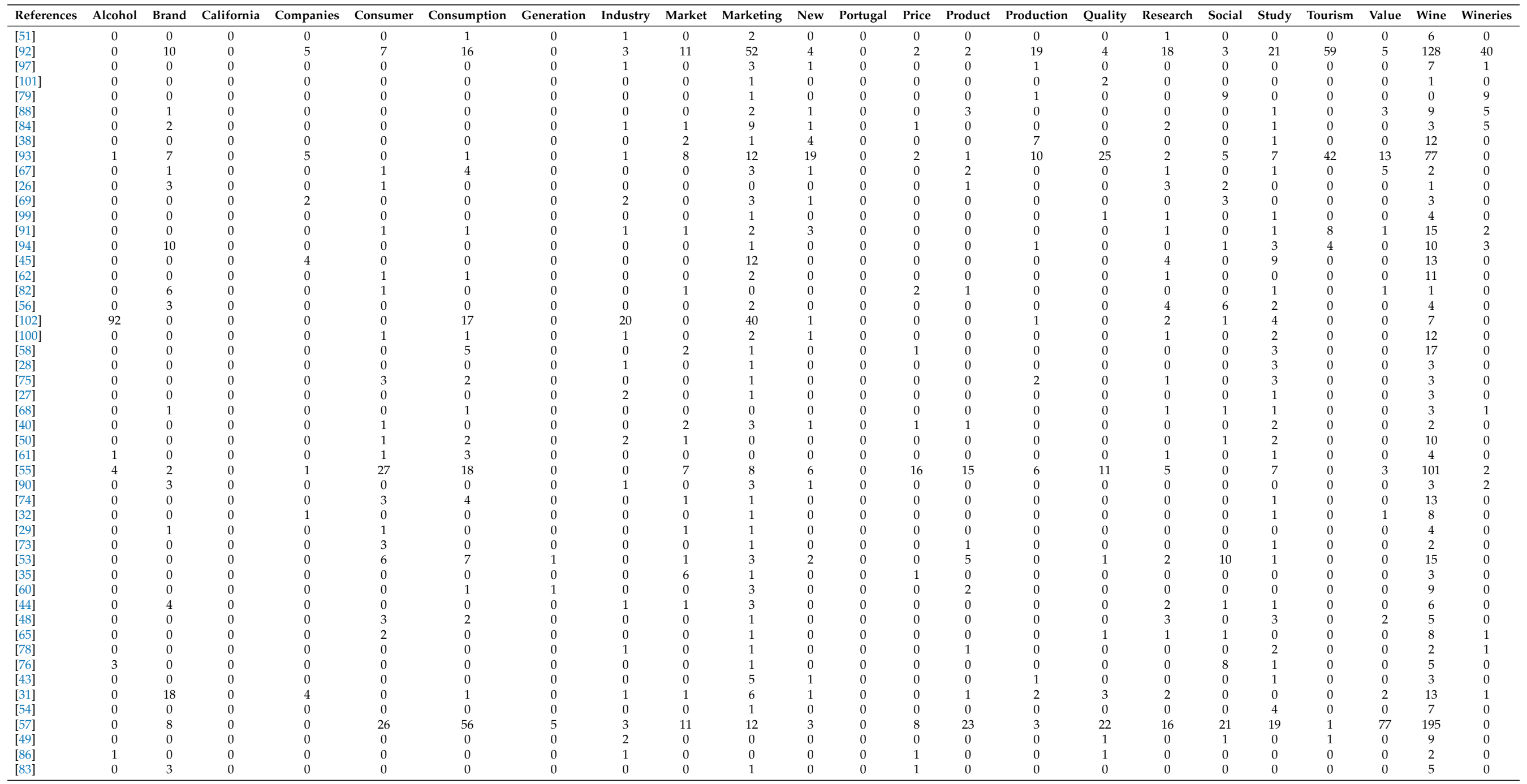


Table A1. Cont.

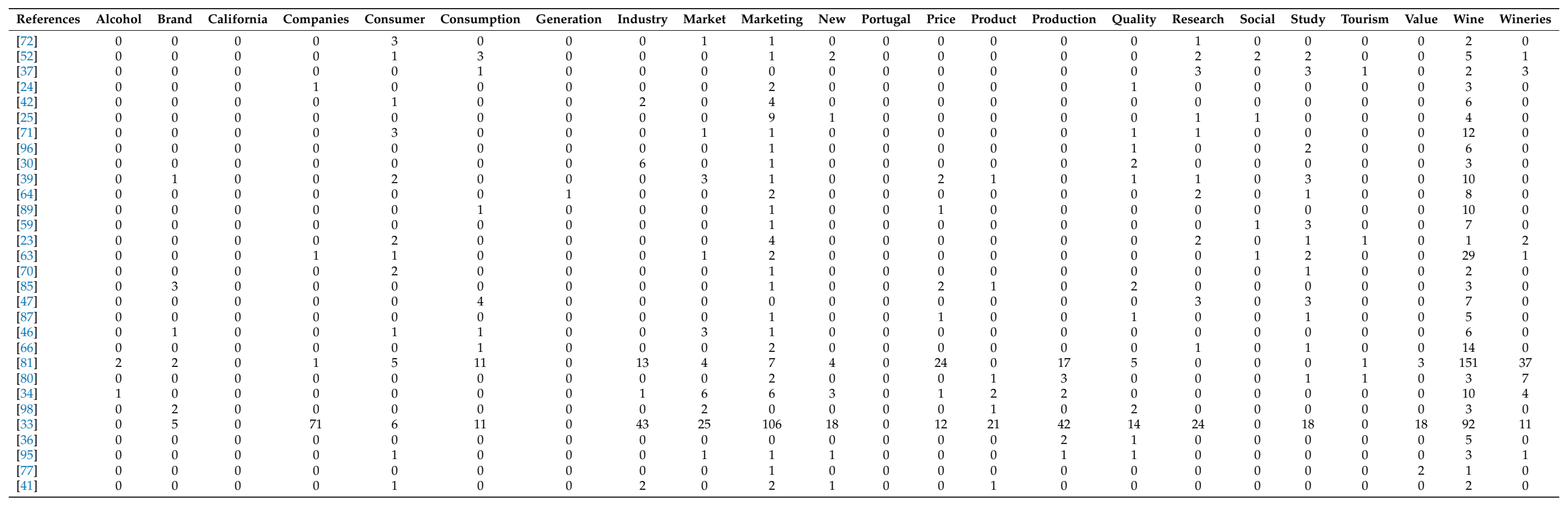

Table A2. Scientific documents grouped by index, considering the weight of each word (by document) in total.

\begin{tabular}{|c|c|c|c|c|c|c|c|c|c|c|c|c|c|c|c|c|c|c|c|}
\hline \multirow[t]{2}{*}{ References } & \multicolumn{6}{|c|}{ Supply Index } & \multicolumn{7}{|c|}{ Demand Index } & \multicolumn{2}{|c|}{ Winery Strategy Index } & \multirow{2}{*}{$\begin{array}{c}\text { Tourism Index } \\
\text { Tourism }\end{array}$} & \multicolumn{2}{|c|}{ Innovation Index } & \multirow{2}{*}{$\begin{array}{c}\text { Wine Characteristics Index } \\
\text { Alcohol }\end{array}$} \\
\hline & Companies & Industry & Market & Marketing & Production & Research & Consumer & Consumption & Generation & Product & Social & Value & Wine & Price & Wineries & & Quality & New & \\
\hline [51] & 0.000 & 0.009 & 0.000 & 0.005 & 0.000 & 0.009 & 0.000 & 0.006 & 0.000 & 0.000 & 0.000 & 0.000 & 0.005 & 0.000 & 0.000 & 0.000 & 0.000 & 0.000 & 0.000 \\
\hline$[38]$ & 0.000 & 0.000 & 0.019 & 0.003 & 0.058 & 0.000 & 0.000 & 0.000 & 0.000 & 0.000 & 0.000 & 0.000 & 0.010 & 0.000 & 0.000 & 0.000 & 0.000 & 0.049 & 0.000 \\
\hline$[26]$ & 0.000 & 0.000 & 0.000 & 0.000 & 0.000 & 0.026 & 0.008 & 0.000 & 0.000 & 0.011 & 0.025 & 0.000 & 0.001 & 0.000 & 0.000 & 0.000 & 0.000 & 0.000 & 0.000 \\
\hline [45] & 0.042 & 0.000 & 0.000 & 0.032 & 0.000 & 0.034 & 0.000 & 0.000 & 0.000 & 0.000 & 0.000 & 0.000 & 0.011 & 0.000 & 0.000 & 0.000 & 0.000 & 0.000 & 0.000 \\
\hline [28] & 0.000 & 0.009 & 0.000 & 0.003 & 0.000 & 0.000 & 0.000 & 0.000 & 0.000 & 0.000 & 0.000 & 0.000 & 0.002 & 0.000 & 0.000 & 0.000 & 0.000 & 0.000 & 0.000 \\
\hline [27] & 0.000 & 0.018 & 0.000 & 0.003 & 0.000 & 0.000 & 0.000 & 0.000 & 0.000 & 0.000 & 0.000 & 0.000 & 0.002 & 0.000 & 0.000 & 0.000 & 0.000 & 0.000 & 0.000 \\
\hline [40] & 0.000 & 0.000 & 0.019 & 0.008 & 0.000 & 0.000 & 0.008 & 0.000 & 0.000 & 0.011 & 0.000 & 0.000 & 0.002 & 0.013 & 0.000 & 0.000 & 0.000 & 0.012 & 0.000 \\
\hline [50] & 0.000 & 0.018 & 0.010 & 0.000 & 0.000 & 0.000 & 0.008 & 0.011 & 0.000 & 0.000 & 0.013 & 0.000 & 0.008 & 0.000 & 0.000 & 0.000 & 0.000 & 0.000 & 0.000 \\
\hline [32] & 0.010 & 0.000 & 0.000 & 0.003 & 0.000 & 0.000 & 0.000 & 0.000 & 0.000 & 0.000 & 0.000 & 0.007 & 0.007 & 0.000 & 0.000 & 0.000 & 0.000 & 0.000 & 0.000 \\
\hline [29] & 0.000 & 0.000 & 0.010 & 0.003 & 0.000 & 0.000 & 0.008 & 0.000 & 0.000 & 0.000 & 0.000 & 0.000 & 0.003 & 0.000 & 0.000 & 0.000 & 0.000 & 0.000 & 0.000 \\
\hline [35] & 0.000 & 0.000 & 0.057 & 0.003 & 0.000 & 0.000 & 0.000 & 0.000 & 0.000 & 0.000 & 0.000 & 0.000 & 0.002 & 0.013 & 0.000 & 0.000 & 0.000 & 0.000 & 0.000 \\
\hline
\end{tabular}


Table A2. Cont.

\begin{tabular}{|c|c|c|c|c|c|c|c|c|c|c|c|c|c|c|c|c|c|c|c|}
\hline \multirow[t]{2}{*}{ References } & \multicolumn{6}{|c|}{ Supply Index } & \multicolumn{7}{|c|}{ Demand Index } & \multicolumn{2}{|c|}{ Winery Strategy Index } & \multirow{2}{*}{$\begin{array}{c}\text { Tourism Index } \\
\text { Tourism }\end{array}$} & \multicolumn{2}{|c|}{ Innovation Index } & \multirow{2}{*}{$\begin{array}{c}\text { Wine Characteristics Inder } \\
\text { Alcohol }\end{array}$} \\
\hline & Companies & Industry & Market & Marketing & Production & Research & Consumer & Consumption & Generation & Product & Social & Value & Wine & Price & Wineries & & Quality & New & \\
\hline [44] & 0.000 & 0.009 & 0.010 & 0.008 & 0.000 & 0.017 & 0.000 & 0.000 & 0.000 & 0.000 & 0.013 & 0.000 & 0.005 & 0.000 & 0.000 & 0.000 & 0.000 & 0.000 & 0.000 \\
\hline [48] & 0.000 & 0.000 & 0.000 & 0.003 & 0.000 & 0.026 & 0.025 & 0.011 & 0.000 & 0.000 & 0.000 & 0.015 & 0.004 & 0.000 & 0.000 & 0.000 & 0.000 & 0.000 & 0.000 \\
\hline [43] & 0.000 & 0.000 & 0.000 & 0.013 & 0.008 & 0.000 & 0.000 & 0.000 & 0.000 & 0.000 & 0.000 & 0.000 & 0.002 & 0.000 & 0.000 & 0.000 & 0.000 & 0.012 & 0.000 \\
\hline [31] & 0.042 & 0.009 & 0.010 & 0.016 & 0.017 & 0.017 & 0.000 & 0.006 & 0.000 & 0.011 & 0.000 & 0.015 & 0.011 & 0.000 & 0.007 & 0.000 & 0.029 & 0.012 & 0.000 \\
\hline [49] & 0.000 & 0.018 & 0.000 & 0.000 & 0.000 & 0.000 & 0.000 & 0.000 & 0.000 & 0.000 & 0.013 & 0.000 & 0.007 & 0.000 & 0.000 & 0.008 & 0.010 & 0.000 & 0.000 \\
\hline [37] & 0.000 & 0.000 & 0.000 & 0.000 & 0.000 & 0.026 & 0.000 & 0.006 & 0.000 & 0.000 & 0.000 & 0.000 & 0.002 & 0.000 & 0.021 & 0.008 & 0.000 & 0.000 & 0.000 \\
\hline [24] & 0.010 & 0.000 & 0.000 & 0.005 & 0.000 & 0.000 & 0.000 & 0.000 & 0.000 & 0.000 & 0.000 & 0.000 & 0.002 & 0.000 & 0.000 & 0.000 & 0.010 & 0.000 & 0.000 \\
\hline$[42]$ & 0.000 & 0.018 & 0.000 & 0.011 & 0.000 & 0.000 & 0.008 & 0.000 & 0.000 & 0.000 & 0.000 & 0.000 & 0.005 & 0.000 & 0.000 & 0.000 & 0.000 & 0.000 & 0.000 \\
\hline [25] & 0.000 & 0.000 & 0.000 & 0.024 & 0.000 & 0.009 & 0.000 & 0.000 & 0.000 & 0.000 & 0.013 & 0.000 & 0.003 & 0.000 & 0.000 & 0.000 & 0.000 & 0.012 & 0.000 \\
\hline [30] & 0.000 & 0.053 & 0.000 & 0.003 & 0.000 & 0.000 & 0.000 & 0.000 & 0.000 & 0.000 & 0.000 & 0.000 & 0.002 & 0.000 & 0.000 & 0.000 & 0.019 & 0.000 & 0.000 \\
\hline [39] & 0.000 & 0.000 & 0.029 & 0.003 & 0.000 & 0.009 & 0.017 & 0.000 & 0.000 & 0.011 & 0.000 & 0.000 & 0.008 & 0.025 & 0.000 & 0.000 & 0.010 & 0.000 & 0.000 \\
\hline [47] & 0.000 & 0.000 & 0.000 & 0.000 & 0.000 & 0.026 & 0.000 & 0.023 & 0.000 & 0.000 & 0.000 & 0.000 & 0.006 & 0.000 & 0.000 & 0.000 & 0.000 & 0.000 & 0.000 \\
\hline [46] & 0.000 & 0.000 & 0.029 & 0.003 & 0.000 & 0.000 & 0.008 & 0.006 & 0.000 & 0.000 & 0.000 & 0.000 & 0.005 & 0.000 & 0.000 & 0.000 & 0.000 & 0.000 & 0.000 \\
\hline [34] & 0.000 & 0.009 & 0.057 & 0.016 & 0.017 & 0.000 & 0.000 & 0.000 & 0.000 & 0.023 & 0.000 & 0.000 & 0.008 & 0.013 & 0.029 & 0.000 & 0.000 & 0.037 & 0.010 \\
\hline [33] & 0.740 & 0.381 & 0.238 & 0.283 & 0.347 & 0.207 & 0.050 & 0.062 & 0.000 & 0.241 & 0.000 & 0.132 & 0.076 & 0.152 & 0.079 & 0.000 & 0.135 & 0.220 & 0.000 \\
\hline [36] & 0.000 & 0.000 & 0.000 & 0.000 & 0.017 & 0.000 & 0.000 & 0.000 & 0.000 & 0.000 & 0.000 & 0.000 & 0.004 & 0.000 & 0.000 & 0.000 & 0.010 & 0.000 & 0.000 \\
\hline [41] & 0.000 & 0.018 & 0.000 & 0.005 & 0.000 & 0.000 & 0.008 & 0.000 & 0.000 & 0.011 & 0.000 & 0.000 & 0.002 & 0.000 & 0.000 & 0.000 & 0.000 & 0.012 & 0.000 \\
\hline [79] & 0.000 & 0.000 & 0.000 & 0.003 & 0.008 & 0.000 & 0.000 & 0.000 & 0.000 & 0.000 & 0.114 & 0.000 & 0.000 & 0.000 & 0.064 & 0.000 & 0.000 & 0.000 & 0.000 \\
\hline [67] & 0.000 & 0.000 & 0.000 & 0.008 & 0.000 & 0.009 & 0.008 & 0.023 & 0.000 & 0.023 & 0.000 & 0.037 & 0.002 & 0.000 & 0.000 & 0.000 & 0.000 & 0.012 & 0.000 \\
\hline [69] & 0.021 & 0.018 & 0.000 & 0.008 & 0.000 & 0.000 & 0.000 & 0.000 & 0.000 & 0.000 & 0.038 & 0.000 & 0.002 & 0.000 & 0.000 & 0.000 & 0.000 & 0.012 & 0.000 \\
\hline [62] & 0.000 & 0.000 & 0.000 & 0.005 & 0.000 & 0.009 & 0.008 & 0.006 & 0.000 & 0.000 & 0.000 & 0.000 & 0.009 & 0.000 & 0.000 & 0.000 & 0.000 & 0.000 & 0.000 \\
\hline [56] & 0.000 & 0.000 & 0.000 & 0.005 & 0.000 & 0.034 & 0.000 & 0.000 & 0.000 & 0.000 & 0.076 & 0.000 & 0.003 & 0.000 & 0.000 & 0.000 & 0.000 & 0.000 & 0.000 \\
\hline [58] & 0.000 & 0.000 & 0.019 & 0.003 & 0.000 & 0.000 & 0.000 & 0.028 & 0.000 & 0.000 & 0.000 & 0.000 & 0.014 & 0.013 & 0.000 & 0.000 & 0.000 & 0.000 & 0.000 \\
\hline [61] & 0.000 & 0.000 & 0.000 & 0.000 & 0.000 & 0.009 & 0.008 & 0.017 & 0.000 & 0.000 & 0.000 & 0.000 & 0.003 & 0.000 & 0.000 & 0.000 & 0.000 & 0.000 & 0.010 \\
\hline [55] & 0.010 & 0.000 & 0.067 & 0.021 & 0.050 & 0.043 & 0.227 & 0.102 & 0.000 & 0.172 & 0.000 & 0.022 & 0.084 & 0.203 & 0.014 & 0.000 & 0.106 & 0.073 & 0.038 \\
\hline [74] & 0.000 & 0.000 & 0.010 & 0.003 & 0.000 & 0.000 & 0.025 & 0.023 & 0.000 & 0.000 & 0.000 & 0.000 & 0.011 & 0.000 & 0.000 & 0.000 & 0.000 & 0.000 & 0.000 \\
\hline [73] & 0.000 & 0.000 & 0.000 & 0.003 & 0.000 & 0.000 & 0.025 & 0.000 & 0.000 & 0.011 & 0.000 & 0.000 & 0.002 & 0.000 & 0.000 & 0.000 & 0.000 & 0.000 & 0.000 \\
\hline [53] & 0.000 & 0.000 & 0.010 & 0.008 & 0.000 & 0.017 & 0.050 & 0.040 & 0.125 & 0.057 & 0.127 & 0.000 & 0.012 & 0.000 & 0.000 & 0.000 & 0.010 & 0.024 & 0.000 \\
\hline [60] & 0.000 & 0.000 & 0.000 & 0.008 & 0.000 & 0.000 & 0.000 & 0.006 & 0.125 & 0.023 & 0.000 & 0.000 & 0.007 & 0.000 & 0.000 & 0.000 & 0.000 & 0.000 & 0.000 \\
\hline [65] & 0.000 & 0.000 & 0.000 & $\begin{array}{l}0.000 \\
0.003\end{array}$ & 0.000 & 0.009 & 0.017 & 0.000 & 0.000 & 0.000 & 0.013 & 0.000 & 0.007 & 0.000 & 0.007 & 0.000 & 0.010 & 0.000 & 0.000 \\
\hline [78] & 0.000 & 0.009 & 0.000 & 0.003 & 0.000 & 0.000 & 0.000 & 0.000 & 0.000 & 0.011 & 0.000 & 0.000 & 0.002 & 0.000 & 0.007 & 0.000 & 0.000 & 0.000 & 0.000 \\
\hline [76] & 0.000 & 0.000 & 0.000 & 0.003 & 0.000 & 0.000 & 0.000 & 0.000 & 0.000 & 0.000 & 0.101 & 0.000 & 0.004 & 0.000 & 0.000 & 0.000 & 0.000 & 0.000 & 0.029 \\
\hline [54] & 0.000 & 0.000 & 0.000 & 0.003 & 0.000 & 0.000 & 0.000 & 0.000 & 0.000 & 0.000 & 0.000 & 0.000 & 0.006 & 0.000 & 0.000 & 0.000 & 0.000 & 0.000 & 0.000 \\
\hline [57] & 0.000 & 0.027 & 0.105 & 0.032 & 0.025 & 0.138 & 0.218 & 0.316 & 0.625 & 0.264 & 0.266 & 0.566 & 0.162 & 0.101 & 0.000 & 0.008 & 0.212 & 0.037 & 0.000 \\
\hline [72] & 0.000 & 0.000 & 0.010 & 0.003 & 0.000 & 0.009 & 0.025 & 0.000 & 0.000 & 0.000 & 0.000 & 0.000 & 0.002 & 0.000 & 0.000 & 0.000 & 0.000 & 0.000 & 0.000 \\
\hline [52] & 0.000 & 0.000 & 0.000 & 0.003 & 0.000 & 0.017 & 0.008 & 0.017 & 0.000 & 0.000 & 0.025 & 0.000 & 0.004 & 0.000 & 0.007 & 0.000 & 0.000 & 0.024 & 0.000 \\
\hline [71] & 0.000 & 0.000 & 0.010 & 0.003 & 0.000 & 0.009 & 0.025 & 0.000 & 0.000 & 0.000 & 0.000 & 0.000 & 0.010 & 0.000 & 0.000 & 0.000 & 0.010 & 0.000 & 0.000 \\
\hline$[64]$ & 0.000 & 0.000 & 0.000 & 0.005 & 0.000 & 0.017 & 0.000 & 0.000 & 0.125 & 0.000 & 0.000 & 0.000 & 0.007 & 0.000 & 0.000 & 0.000 & 0.000 & 0.000 & 0.000 \\
\hline [59] & 0.000 & 0.000 & 0.000 & 0.003 & 0.000 & 0.000 & 0.000 & 0.000 & 0.000 & 0.000 & 0.013 & 0.000 & 0.006 & 0.000 & 0.000 & 0.000 & 0.000 & 0.000 & 0.000 \\
\hline [63] & 0.010 & 0.000 & 0.010 & 0.005 & 0.000 & 0.000 & 0.008 & 0.000 & 0.000 & 0.000 & 0.013 & 0.000 & 0.024 & 0.000 & 0.007 & 0.000 & 0.000 & 0.000 & 0.000 \\
\hline$[70]$ & 0.000 & 0.000 & 0.000 & 0.003 & 0.000 & 0.000 & 0.017 & 0.000 & 0.000 & 0.000 & 0.000 & 0.000 & 0.002 & 0.000 & 0.000 & 0.000 & 0.000 & 0.000 & 0.000 \\
\hline [66] & 0.000 & 0.000 & 0.000 & 0.005 & 0.000 & 0.009 & 0.000 & 0.006 & 0.000 & 0.000 & 0.000 & 0.000 & 0.012 & 0.000 & 0.000 & 0.000 & 0.000 & 0.000 & 0.000 \\
\hline [77] & 0.000 & 0.000 & 0.000 & 0.003 & 0.000 & 0.000 & 0.000 & 0.000 & 0.000 & 0.000 & 0.000 & 0.015 & 0.001 & 0.000 & 0.000 & 0.000 & 0.000 & 0.000 & 0.000 \\
\hline [88] & 0.000 & 0.000 & 0.000 & 0.005 & 0.000 & 0.000 & 0.000 & 0.000 & 0.000 & 0.034 & 0.000 & 0.022 & 0.007 & 0.000 & 0.036 & 0.000 & 0.000 & 0.012 & 0.000 \\
\hline
\end{tabular}


Table A2. Cont.

\begin{tabular}{|c|c|c|c|c|c|c|c|c|c|c|c|c|c|c|c|c|c|c|c|}
\hline \multirow{2}{*}{ References } & \multicolumn{6}{|c|}{ Supply Index } & \multicolumn{7}{|c|}{ Demand Index } & \multicolumn{2}{|c|}{ Winery Strategy Index } & \multirow{2}{*}{$\begin{array}{c}\text { Tourism Index } \\
\text { Tourism }\end{array}$} & \multicolumn{2}{|c|}{ Innovation Index } & \multirow{2}{*}{$\begin{array}{c}\text { Wine Characteristics Index } \\
\text { Alcohol }\end{array}$} \\
\hline & Companies & Industry & Market & Marketing & Production & Research & Consumer & Consumption & Generation & Product & Social & Value & Wine & Price & Wineries & & Quality & New & \\
\hline [84] & 0.000 & 0.009 & 0.010 & 0.024 & 0.000 & 0.017 & 0.000 & 0.000 & 0.000 & 0.000 & 0.000 & 0.000 & 0.002 & 0.013 & 0.036 & 0.000 & 0.000 & 0.012 & 0.000 \\
\hline [82] & 0.000 & 0.000 & 0.010 & 0.000 & 0.000 & 0.000 & 0.008 & 0.000 & 0.000 & 0.011 & 0.000 & 0.007 & 0.001 & 0.025 & 0.000 & 0.000 & 0.000 & 0.000 & 0.000 \\
\hline [90] & 0.000 & 0.009 & 0.000 & 0.008 & 0.000 & 0.000 & 0.000 & 0.000 & 0.000 & 0.000 & 0.000 & 0.000 & 0.002 & 0.000 & 0.014 & 0.000 & 0.000 & 0.012 & 0.000 \\
\hline [86] & 0.000 & 0.009 & 0.000 & 0.000 & 0.000 & 0.000 & 0.000 & 0.000 & 0.000 & 0.000 & 0.000 & 0.000 & 0.002 & 0.013 & 0.000 & 0.000 & 0.010 & 0.000 & 0.010 \\
\hline [83] & 0.000 & 0.000 & 0.000 & 0.003 & 0.000 & 0.000 & 0.000 & 0.000 & 0.000 & 0.000 & 0.000 & 0.000 & 0.004 & 0.013 & 0.000 & 0.000 & 0.000 & 0.000 & 0.000 \\
\hline [89] & 0.000 & 0.000 & 0.000 & 0.003 & 0.000 & 0.000 & 0.000 & 0.006 & 0.000 & 0.000 & 0.000 & 0.000 & 0.008 & 0.013 & 0.000 & 0.000 & 0.000 & 0.000 & 0.000 \\
\hline [85] & 0.000 & 0.000 & 0.000 & 0.003 & 0.000 & 0.000 & 0.000 & 0.000 & 0.000 & 0.011 & 0.000 & 0.000 & 0.002 & 0.025 & 0.000 & 0.000 & 0.019 & 0.000 & 0.000 \\
\hline [87] & 0.000 & 0.000 & 0.000 & 0.003 & 0.000 & 0.000 & 0.000 & 0.000 & 0.000 & 0.000 & 0.000 & 0.000 & 0.004 & 0.013 & 0.000 & 0.000 & 0.010 & 0.000 & 0.000 \\
\hline [81] & 0.010 & 0.115 & 0.038 & 0.019 & 0.140 & 0.000 & 0.042 & 0.062 & 0.000 & 0.000 & 0.000 & 0.022 & 0.125 & 0.304 & 0.264 & 0.008 & 0.048 & 0.049 & 0.019 \\
\hline [80] & 0.000 & 0.000 & 0.000 & 0.005 & 0.025 & 0.000 & 0.000 & 0.000 & 0.000 & 0.011 & 0.000 & 0.000 & 0.002 & 0.000 & 0.050 & 0.008 & 0.000 & 0.000 & 0.000 \\
\hline [92] & 0.052 & 0.027 & 0.105 & 0.139 & 0.157 & 0.155 & 0.059 & 0.090 & 0.000 & 0.023 & 0.038 & 0.037 & 0.106 & 0.025 & 0.286 & 0.496 & 0.038 & 0.049 & 0.000 \\
\hline [91] & 0.000 & 0.009 & 0.010 & 0.005 & 0.000 & 0.009 & 0.008 & 0.006 & 0.000 & 0.000 & 0.000 & 0.007 & 0.012 & 0.000 & 0.014 & 0.067 & 0.000 & 0.037 & 0.000 \\
\hline [94] & 0.000 & 0.000 & 0.000 & 0.003 & 0.008 & 0.000 & 0.000 & 0.000 & 0.000 & 0.000 & 0.013 & 0.000 & 0.008 & 0.000 & 0.021 & 0.034 & 0.000 & 0.000 & 0.000 \\
\hline [97] & 0.000 & 0.009 & 0.000 & 0.008 & 0.008 & 0.000 & 0.000 & 0.000 & 0.000 & 0.000 & 0.000 & 0.000 & 0.006 & 0.000 & 0.007 & 0.000 & 0.000 & 0.012 & 0.000 \\
\hline [101] & 0.000 & 0.000 & 0.000 & 0.003 & 0.000 & 0.000 & 0.000 & 0.000 & 0.000 & 0.000 & 0.000 & 0.000 & 0.001 & 0.000 & 0.000 & 0.000 & 0.019 & 0.000 & 0.000 \\
\hline [99] & 0.000 & 0.000 & 0.000 & 0.003 & 0.000 & 0.009 & 0.000 & 0.000 & 0.000 & 0.000 & 0.000 & 0.000 & 0.003 & 0.000 & 0.000 & 0.000 & 0.010 & 0.000 & 0.000 \\
\hline [100] & 0.000 & 0.009 & 0.000 & 0.005 & 0.000 & 0.009 & 0.008 & 0.006 & 0.000 & 0.000 & 0.000 & 0.000 & 0.010 & 0.000 & 0.000 & 0.000 & 0.000 & 0.012 & 0.000 \\
\hline [96] & 0.000 & 0.000 & 0.000 & 0.003 & 0.000 & 0.000 & 0.000 & 0.000 & 0.000 & 0.000 & 0.000 & 0.000 & 0.005 & 0.000 & 0.000 & 0.000 & 0.010 & 0.000 & 0.000 \\
\hline [98] & 0.000 & 0.000 & 0.019 & 0.000 & 0.000 & 0.000 & 0.000 & 0.000 & 0.000 & 0.011 & 0.000 & 0.000 & 0.002 & 0.000 & 0.000 & 0.000 & 0.019 & 0.000 & 0.000 \\
\hline [95] & 0.000 & 0.000 & 0.010 & 0.003 & 0.008 & 0.000 & 0.008 & 0.000 & 0.000 & 0.000 & 0.000 & 0.000 & 0.002 & 0.000 & 0.007 & 0.000 & 0.010 & 0.012 & 0.000 \\
\hline [102] & 0.000 & 0.177 & 0.000 & 0.107 & 0.008 & 0.017 & 0.000 & 0.096 & 0.000 & 0.000 & 0.013 & 0.000 & 0.006 & 0.000 & 0.000 & 0.000 & 0.000 & 0.012 & 0.876 \\
\hline
\end{tabular}




\section{References}

1. OIV. World Vitiviniculture Situation. Available online: http://www.oiv.int/public/medias/5597/ppt-en-40thoivcongressbulgaria.pdf (accessed on 26 November 2018).

2. Boncinelli, F.; Dominici, A.; Gerini, F.; Marone, E. Consumers Wine Preferences According to Purchase Occasion: Personal Consumption and Gift-Giving. Food. Qual. Prefer. 2019, 71, 270-278. [CrossRef]

3. Web of Science. Web of Science-Main Databases. Available online: http://apps.webofknowledge.com/WOS_GeneralSearch_ input.do?product=WOS\&SID=F6V4qkYCxMqypJDb5Pu\&search_mode=GeneralSearch (accessed on 26 November 2018).

4. Scopus. Scopus Database. Available online: https://www.scopus.com/home.uri (accessed on 26 November 2018).

5. Web of Science. Web of Science-All Databases. Available online: http://apps.webofknowledge.com/UA_GeneralSearch_input. do? product=UA\&SID=F6V4qkYCxMqypJDb5Pu\&search_mode=GeneralSearch (accessed on 21 February 2019).

6. Liberati, A.; Altman, D.G.; Tetzlaff, J.; Mulrow, C.; Gøtzsche, P.C.; Ioannidis, J.P.A.; Clarke, M.; Devereaux, P.J.; Kleijnen, J.; Moher, D. The PRISMA Statement for Reporting Systematic Reviews and Meta-Analyses of Studies That Evaluate Healthcare Interventions: Explanation and Elaboration. BMJ 2009, 339, b2700. [CrossRef]

7. Martinho, V.J.P.D. Agri-Food Contexts in Mediterranean Regions: Contributions to Better Resources Management. Sustainability 2021, 13, 6683. [CrossRef]

8. Giacomarra, M.; Galati, A.; Crescimanno, M.; Tinervia, S. The Integration of Quality and Safety Concerns in the Wine Industry: The Role of Third-Party Voluntary Certifications. J. Clean. Prod. 2016, 112, 267-274. [CrossRef]

9. Golbabaei, F.; Yigitcanlar, T.; Paz, A.; Bunker, J. Individual Predictors of Autonomous Vehicle Public Acceptance and Intention to Use: A Systematic Review of the Literature. J. Open Innov. Technol. Mark. Complex. 2020, 6, 106. [CrossRef]

10. González-Rubio, J.; Navarro-López, C.; López-Nájera, E.; López-Nájera, A.; Jiménez-Díaz, L.; Navarro-López, J.D.; Nájera, A. A Systematic Review and Meta-Analysis of Hospitalised Current Smokers and COVID-19. Int. J. Environ. Res. Public Health 2020, 17, 7394. [CrossRef] [PubMed]

11. Leonidou, E.; Christofi, M.; Vrontis, D.; Thrassou, A. An Integrative Framework of Stakeholder Engagement for Innovation Management and Entrepreneurship Development. J. Bus. Res. 2020, 119, 245-258. [CrossRef]

12. Maesano, G.; Di Vita, G.; Chinnici, G.; Pappalardo, G.; D'Amico, M. The Role of Credence Attributes in Consumer Choices of Sustainable Fish Products: A Review. Sustainability 2020, 12, 8. [CrossRef]

13. Hamam, M.; Chinnici, G.; Di Vita, G.; Pappalardo, G.; Pecorino, B.; Maesano, G.; D'Amico, M. Circular Economy Models in Agro-Food Systems: A Review. Sustainability 2021, 13, 3453. [CrossRef]

14. Martinho, V.J.P.D. Interrelationships between Renewable Energy and Agricultural Economics: An Overview. Energy Strategy Rev. 2018, 22, 396-409. [CrossRef]

15. Martinho, V.J.P.D. Best Management Practices from Agricultural Economics: Mitigating Air, Soil and Water Pollution. Sci. Total Environ. 2019, 688, 346-360. [CrossRef]

16. VOSviewer. VOSviewer-Visualizing Scientific Landscapes. Available online: http://www.vosviewer.com// (accessed on 26 November 2018).

17. Atlas.ti ATLAS.Ti: The Qualitative Data Analysis \& Research Software. Available online: http://atlasti.com/ (accessed on 26 November 2018).

18. Van Eck, N.J.; Waltman, L. VOSviewer Manual. 51. Available online: https:/ /www.vosviewer.com/documentation/Manual_ VOSviewer_1.6.8.pdf (accessed on 26 November 2018).

19. Stata. Stata: Data Analysis and Statistical Software. Available online: https://www.stata.com/ (accessed on 26 November 2018).

20. Torres-Reyna, O. Getting Started in Factor Analysis (Using Stata 10) (Ver. 1.5). Available online: https://www.princeton.edu/ $\sim\{\}$ otorres/Factor.pdf (accessed on 21 February 2019).

21. Filho, D.B.F.; da Silva Júnior, J.A. Visão além do alcance: Uma introdução à análise fatorial. Opinião Pública 2010, 16, 160-185. [CrossRef]

22. Hair, J.F.; Black, W.C.; Babin, B.J.; Anderson, R.E. Multivariate Data Analysis, 7th ed.; Pearson: Upper Saddle River, NJ, USA, 2009; ISBN 978-0-13-813263-7.

23. Alonso, A.D. The Red-Headed Stepchild of Wine? Marketing Muscadine Wines in the Southern USA. Br. Food J. 2011, 113, 1290-1304. [CrossRef]

24. Coskun, L.; Herzka, P. Contribution of Internet Marketing Communication on Competitiveness of Wine Companies. In Proceedings of the Aktualne Problemy Podnikovej Sfery, Bratislava, Slovakia, 16 May 2013; pp. 47-52.

25. Zongda, L.; Jiagui, L. Analysis of Wine Micro-Blogging Marketing Using the Theory of 4Cs. In Proceedings of the Eighth International Symposium on Viticulture and Enology (2013), Huludao, China, 20-22 April 2013; Hua, L., Ed.; Shaanxi Peoples Publ House: Xi'an, China, 2013; pp. 263-268.

26. Dolan, R.; Goodman, S. Succeeding on Social Media: Exploring Communication Strategies for Wine Marketing. J. Hosp. Tour. Manag. 2017, 33, 23-30. [CrossRef]

27. Giwon, K.; Park, S.; Youn, K.J. A Study on The Impacts of EWOM Information Characteristics on Perceived Risk, Perceived Benefit and WOM Effect in Wine Industry. Korean J. Hosp. Tour. 2017, 26, 99-117. 
28. Park, S.-Y.; Giwon, K.; Youn, K.J. An Effect of Wine Consumers' Characteristics of EWOM on WOM Effect and Purchase Intention. J. Foodserv. Manag. 2017, 20, 223-244.

29. Hall, D.; Pitt, L.; Wallstrom, A. The Secrets of Secret Societies: The Case of Wine. Bus. Horiz. 2015, 58, 651-658. [CrossRef]

30. Vink, N.; Deloire, A.; Bonnardot, V.; Ewert, J. Climate Change and the Future of South Africa's Wine Industry. Int. J. Clim. Change Strateg. Manag. 2012, 4, 420-441. [CrossRef]

31. Antonazzo, A.P.; Fiore, M.; Conto, F. Does Organic Certification of Wine Matter for Brand Equity? In Future of Entrepreneurship, Proceedings of the 7th Annual EuroMed Conference of the EuroMed-Academy-of-Business, Kristiansand, Norway, 18-19 September 2014; Vrontis, D., Weber, Y., Tsoukatos, E., Eds.; EuroMed Press: Marseille, France, 2014; pp. 2023-2024.

32. Sogari, G.; Mora, C.; Menozzi, D. Factors Driving Sustainable Choice: The Case of Wine. Br. Food J. 2016, 118, 632-646. [CrossRef]

33. Azabagaoglu, M.O.; Akyol, A.; Ozay, A. Examining the Turkish Wine Industry: Marketing Effectiveness and Recommendations for Increasing Its Competitive Performance. N. Z. J. Crop Hortic. Sci. 2006, 34, 257-268. [CrossRef]

34. Azabagaoglu, M.O.; Akyol, A.; Ozay, A. The Demand for Organic Wines and Organic Wine Marketing. J. Environ. Prot. Ecol. 2007, 8, 171-178.

35. Diaz Osorio, J.; Valdes, R.; Hernandez, N. Chilean Wine in the European Market. A Positioning Mapping Approach from Germany. Rev. Fac. Cienc. Agrar. UNCuyo 2015, 47, 159-171.

36. Baritaux, V.; Aubert, M.; Montaigne, E.; Remaud, H. Matchmakers in Wine Marketing Channels: The Case of French Wine Brokers. Agribusiness 2006, 22, 375-390. [CrossRef]

37. Ciasullo, M.; Festa, G. The Governance of "Collective" Strategies for Internationalization: Small Businesses in the Italian Wine Sector. In Confronting Contemporary Business Challenges Through Management Innovation, Proceedings of the 6th Annual EuroMed Conference of the EuroMed-Academy-of-Business; Cascais, Portugal, 23-24 September 2013, Vrontis, D., Weber, Y., Tsoukatos, E., Eds.; EuroMed Press: Marseille, France, 2013; pp. 575-593.

38. Mann, S.; Beciu, S.; Karbauskas, A. Globalising Chains-Decoupling Grape Production, Wine Production and Wine Exports. Br. Food J. 2018, 120, 703-713. [CrossRef]

39. Chrysochou, P.; Corsi, A.M.; Krystallis, A. What Drives Greek Consumer Preferences for Cask Wine? Br. Food J. 2012, 114, 1072-1084. [CrossRef]

40. Festa, G.; Cuomo, M.T.; Metallo, G.; Festa, A. The (r)Evolution of Wine Marketing Mix: From the 4Ps to the 4Es. J. Bus. Res. 2016, 69, 1550-1555. [CrossRef]

41. Earle, W.T. Government Regulations and the Wine Industry. In Wine In Context: Nutrition—Physiology—Policy, Proceedings of the Wine and Health-Wine in Context: Nutrition, Physiology, Policy, Reno, NV, USA, 24-25 June 1996; Waterhouse, A.L., Rantz, J.M., Eds.; American Society Enology \& Viticulture: Davis, CA, USA, 1996; pp. 81-84.

42. Tianzhu, H.; Huan, W. Comparison of Wine Marketing Model Between China and Australia. In Proceedings of the Eighth International Symposium on Viticulture and Enology (2013), Huludao, China, 20-22 April 2013; Hua, L., Ed.; Shaanxi Peoples Publ House: Xi'an, China, 2013; pp. 258-262.

43. Soos, G.; David, L. Wine Marketing-Tools for Innovation, Creativity and Sustainability. In Proceedings of the Basiq 2015 International Conference: New Trends in Sustainable Business and Consumption, Bucharest, Romania, 18-19 June 2015; pp. 473-480.

44. Yao, W.; Baumann, C.; Tan, L.P. Wine Brand Category Choice and Confucianism: A Purchase Motivation Comparison of Caucasian, Chinese and Korean Consumers. In Advances in National Brand and Private Label Marketing; Martinez Lopez, F.J., Gazquez Abad, J.C., Sethuraman, R., Eds.; Springer: Cham, Switzerland, 2015; pp. 19-33.

45. Murinova, A. Wine Marketing: The Case of Micro and Small Wine Companies in the Czech Republic. In Proceedings of the 5th International Conference Innovation Management, Entrepreneurship and Sustainability (IMES 2017), Prague, Czech Republic, 25-26 May 2017; Dvoulety, O., Lukes, M., Misar, J., Eds.; Oeconomica Publishing House, Univ Economics: Prague, Czech Republic, 2017; pp. 641-653.

46. TianZhu, H.; Bowen, W.; Jiagui, L. Analysis between Wine Consumption and Resident Income in Ecumenical Town of North China. In Proceedings of the Sixth International Symposium on Viticulture and Enology, Yangling, China, 20-22 April 2009; pp. 327-331.

47. Vrontis, D.; Gunay, G.N. A Comparative Study Between Cyprus and Turkey on Factors Influencing Young Consumers' Wine Behaviours. In Proceedings of the 3rd Annual Euromed Conference of the Euromed Academy of Business: Business Developments across Countries and Cultures, Nicosia, Cyprus, 4-5 November 2010; Vrontis, D., Weber, Y., Kaufmann, H.R., Tarba, S., Eds.; EuroMed Press: Marseille, France, 2010; p. 1486.

48. Choi, Y.H. A Study on the Effect the Purchasing Motivation of Wine Consumers Impact on Purchasing Attribute and Consumption Value. J. Hosp. Tour. Stud. 2015, 17, 184-198.

49. Ramsak, M. Wine Queens: Individual and Cultural Brand Management Process. Rev. Etnogr. Folclor J. Ethnogr. Folk. 2014, 46-63.

50. Velikova, N.; Wilkinson, K.T.; Harp, S.S. Reaching the US Hispanic Wine Market: Highlighting the Opportunities. J. Food Prod. Mark. 2016, 22, 43-64. [CrossRef]

51. Spence, C. Multisensory Experiential Wine Marketing. Food Qual. Prefer. 2019, 71, 106-116. [CrossRef] 
52. Agnoli, L.; Capitello, R.; Begalli, D. Factors Influencing the Decision-Making Process of the New Wine Consumers. In Confronting Contemporary Business Challenges Through Management Innovation, Proceedings of the 6th Annual EuroMed Conference of the EuroMedAcademy-of-Business, Cascais, Portugal, 23-24 September 2013; Vrontis, D., Weber, Y., Tsoukatos, E., Eds.; EuroMed Press: Marseille, France, 2013; pp. 40-52.

53. Marques, C.P.; Guia, A.T.B. A Influência Do Género e Da Ocasião Na Frequência de Consumo de Vinho. Tour. Manag. Stud. 2015, 11, 226-233. [CrossRef]

54. Sung, H.-J.; Kim, J. The Effect of Wine Selection Attribution of Wine Consumers on Satisfaction and Psychological Well-Being. Korean J. Tour. Res. 2014, 29, 219-236.

55. Bernabeu, R.; Diaz, M.; Oliveira, F. Consumer Preferences for Red Wine in the Spanish Market. Ciência e Técnica Vitivinícola 2016, 31, 88-97. [CrossRef]

56. Dolan, R.; Conduit, J.; Fahy, J.; Goodman, S. Social Media: Communication Strategies, Engagement and Future Research Directions. Int. J. Wine Bus. Res. 2017, 29, 2-19. [CrossRef]

57. Wiedmann, K.-P.; Behrens, S.; Klarmann, C.; Hennigs, N. Customer Value Perception: Cross-Generational Preferences for Wine. Br. Food J. 2014, 116, 1128-1142. [CrossRef]

58. Lee, J.-Y. A Study on the Differences in Wine Consumption Behavior and Wine Selection Attributes by Age. J. Foodserv. Manag. 2017, 20, 99-116.

59. Lee, S.H.; Lee, H.-R. The Effect of the Wine Consumers According to the Level of Involvement in Perceived Risk and Information Search on Consumer Satisfaction. J. Foodserv. Manag. 2012, 15, 297-319.

60. Chivu-Draghia, C.; Antoce, A.O. Application of Usability Concepts in Wine Marketing: A Multidisciplinary Review. Agrolife Sci. J. 2015, 4, 32-45.

61. Chivu-Draghia, C.; Antoce, A.O. Understanding Consumer Preferences for Wine: A Comparison Between Millennials and Generation X. Sci. Pap. Ser. Manag. Econ. Eng. Agric. Rural Dev. 2016, 16, 75-83.

62. Lategan, B.W.; Pentz, C.D.; du Preez, R. Importance of Wine Attributes: A South African Generation Y Perspective. Br. Food J. 2017, 119, 1536-1546. [CrossRef]

63. Li, J.-G.; Jia, J.-R.; Taylor, D.; Bruwer, J.; Li, E. The Wine Drinking Behaviour of Young Adults: An Exploratory Study in China. Br. Food J. 2011, 113, 1305-1317. [CrossRef]

64. Chrysochou, P.; Krystallis, A.; Mocanu, A.; Lewis, R.L. Generation Y Preferences for Wine An Exploratory Study of the US Market Applying the Best-Worst Scaling. Br. Food J. 2012, 114, 516-528. [CrossRef]

65. Sogari, G.; Corbo, C.; Macconi, M.; Menozzi, D.; Mora, C. Consumer Attitude towards Sustainable-Labelled Wine: An Exploratory Approach. Int. J. Wine Bus. Res. 2015, 27, 312-328. [CrossRef]

66. Cho, S.-H.; Choi, H.-J. Research on the Differences of Selection Attribute According to the Involvement of Wine Consumers. Korean J. Culin. Res. 2009, 15, 240-253.

67. Dobele, A.R.; Greenacre, L.; Fry, J. The Impact of Purchase Goal on Wine Purchase Decisions. Int. J. Wine Bus. Res. 2018, 30, 19-41. [CrossRef]

68. Cuomo, M.T.; Tortora, D.; Festa, G.; Giordano, A.; Metallo, G. Exploring Consumer Insights in Wine Marketing: An Ethnographic Research on \#Winelovers. Psychol. Mark. 2016, 33, 1082-1090. [CrossRef]

69. Tomazic, T. The Importance of Social Media from the Wine Marketing Perspective. Lex Localis-J. Local Self-Gov. 2017, 15, 827-844. [CrossRef]

70. Mora, P.; Moscarola, J. Representations of the Emotions Associated with a Wine Purchasing or Consumption Experience. Int. J. Consum. Stud. 2010, 34, 674-683. [CrossRef]

71. Han, E.J.; Sun, J.; Min, H. Determinants of Demand for Wine Consumer. Korean J. Tour. Res. 2013, 28 , 59-73.

72. Torri, L.; Noble, A.C.; Heymann, H. Exploring American and Italian Consumer Preferences for Californian and Italian Red Wines. J. Sci. Food Agric. 2013, 93, 1852-1857. [CrossRef] [PubMed]

73. Vigar-Ellis, D.; Pitt, L.; Berthon, P. Knowing What They Know: A Managerial Perspective on Consumer Knowledge. Bus. Horiz. 2015, 58, 679-685. [CrossRef]

74. Hall, D. Exploring Wine Knowledge, Aesthetics and Ephemerality: Clustering Consumers. Int. J. Wine Bus. Res. 2016, 28, 134-153. [CrossRef]

75. Ryu, E.; Seo, S.W.; Kim, Y. The Effect of Environmental Knowledge and Environmental Concern on the Purchase Intention of Eco-Friendly Wine: Focusing on the Moderating Role of Customer Involvement. J. Tour. Sci. 2017, 41, 183-200. [CrossRef]

76. Barrio, P. An Ephemeral Project on Private Regulation of Viticulture in Mendoza (Argentina) in a Crisis Context: Mendoza's Viticulture Society, 1916-1919. Hist. Soc. 2015, 28, 167-197. [CrossRef]

77. Gow, H.R.; Oliver, L.; Gow, N. Co-Operating to Compete in High Velocity Global Markets: The Strategic Role of Flexible Supply Chain Architectures. In Proceedings of the Paradoxes in Food Chains and Networks; Trienekens, J.H., Omta, S.W.F., Eds.; AgEcon Search: Noordwijk, The Netherlands, 2002; pp. 501-511.

78. Signori, P.; Flint, D.; Golicic, S. Constrained Sustainability Innovation: Insights from an Inductive Study of the Global Wine Industry. In Innovation, Entrepreneurship and Sustainable Value Chain in a Dynamic Environment, Proceedings of the 8th Annual Conference of the EuroMed-Academy-of-Business, Verona, Italy, 16-18 September 2015; Vrontis, D., Weber, Y., Tsoukatos, E., Eds.; EuroMed Press: Marseille, France, 2015; pp. 2037-2051. 
79. Urbano-Lopez de Meneses, B. Wine Image and Positioning on Social Media: An Exploratory Examination of "Castilla y Leon" Wineries in Spain. ITEA Inf. Tec. Econ. Agrar. 2018, 114, 303-321. [CrossRef]

80. Barber, N.A.; Donovan, J.R.; Dodd, T.H. Differences in Tourism Marketing Strategies Between Wineries Based on Size or Location. J. Travel Tour. Mark. 2008, 25, 43-57. [CrossRef]

81. Goodhue, R.; Green, R.; Heien, D.; Martin, P. California Wine Industry Evolving to Compete in 21st Century. Calif. Agric. 2008, 62, 12-18. [CrossRef]

82. Blair, A.J.; Atanasova, C.; Pitt, L.; Chan, A.; Wallstrom, A. Assessing Brand Equity in the Luxury Wine Market by Exploiting Tastemaker Scores. J. Prod. Brand Manag. 2017, 26, 447-452. [CrossRef]

83. Priilaid, D.; Barendse, J.; Kato-Kalule, C.; Mubangizi, A. Flies in Amber: Capturing Brand Equity-Effects in South African Rose Wines. South Afr. J. Bus. Manag. 2013, 44, 21-30. [CrossRef]

84. Thach, L.; Charters, S.; Cogan-Marie, L. Core Tensions in Luxury Wine Marketing: The Case of Burgundian Wineries. Int. J. Wine Bus. Res. 2018, 30, 343-365. [CrossRef]

85. Priilaid, D.; van Rensburg, P. Symbolic and Functional Brand Effects in the Hedonic Assessment of South African Wines. South Afr. J. Bus. Manag. 2010, 41, 47-69. [CrossRef]

86. Costanigro, M.; Appleby, C.; Menke, S.D. The Wine Headache: Consumer Perceptions of Sulfites and Willingness to Pay for Non-Sulfited Wines. Food Qual. Prefer. 2014, 31, 81-89. [CrossRef]

87. Youn, K.J.; Yoo, B.; Lee, Y.Y. Wine Marketing Strategies of 5 Star Hotel Restaurants in Seoul Using the Delphi Technique. J. Tour. Sci. 2009, 33, 33-54.

88. Ingrassia, M.; Altamore, L.; Columba, P.; Bacarella, S.; Chironi, S. The Communicative Power of an Extreme Territory-The Italian Island of Pantelleria and Its Passito Wine: A Multidimensional-Framework Study. Int. J. Wine Bus. Res. 2018, 30, $292-308$. [CrossRef]

89. Mann, S.; Ferjani, A.; Reissig, L. What Matters to Consumers of Organic Wine? Br. Food J. 2012, 114, 272-284. [CrossRef]

90. Viana, N.A. Digital Wine Marketing: Social Media Marketing for the Wine Industry. In Proceedings of the 39th World Congress of Vine and Wine, Bento Gonçalves, Brazil, 23-28 October 2016; Aurand, J.M., Ed.; EDP Sciences: Les Ulis, France; Bento Goncalves, Brazil, 2016; Volume 7, p. 03011.

91. Ruediger, J.; Hanf, J.H. The Use of Wine Tourism as a Possibility of the Marketing with Wine Cooperatives. In Proceedings of the 40th World Congress of Vine and Wine, Sofia, Bulgaria, 29 May-2 June 2017; Aurand, J.M., Ed.; EDP Sciences: Les Ulis, France, 2017; Volume 9, p. 03023.

92. Garcia Fernandez, A.; Meraz Ruiz, L.; Diaz Gomez, E.R. Wine Tourism and Wine Marketing in Family-Owned Micro Wineries in Guadalupe Valley, Mexico. Rosa Ventos Tur. Hosp. 2018, 10, 690-711. [CrossRef]

93. Lavrador da Silva, A.; Joao Fernao-Pires, M.; Bianchi-de-Aguiar, F. Portuguese Vines and Wines: Heritage, Quality Symbol, Tourism Asset. Cienc. Tec. Vitivinic. 2018, 33, 31-46. [CrossRef]

94. Morrish, S.C.; Pitt, L.; Vella, J.; Botha, E. Where to Visit, What to Drink? A Cross-National Perspective on Wine Estate Brand Personalities. Int. J. Wine Bus. Res. 2017, 29, 373-383. [CrossRef]

95. Berruto, R.; Tortia, C.; Gay, P. Wine Bottling Scheduling Optimization. Trans. Asabe 2006, 49, 291-295. [CrossRef]

96. Ballester, J.; Mihnea, M.; Peyron, D.; Valentin, D. Exploring Minerality of Burgundy Chardonnay Wines: A Sensory Approach with Wine Experts and Trained Panellists. Aust. J. Grape Wine Res. 2013, 19, 140-152. [CrossRef]

97. Denic, N.; Petkovic, D.; Vujovic, V.; Spasic, B.; Vujicic, I. A Survey of Internet Marketing by Small and Medium-Sized Enterprises for Placing Wine on the Market. Phys. A Stat. Mech. Appl. 2018, 506, 718-727. [CrossRef]

98. Jiagui, L.; Jinrong, J.; Zhongxun, S.; Hecai, Y.; Yabin, W. Study on Differentiated Positioning of Wine Brand Based on Consumer Mentalities. In Proceedings of the Fifth International Symposium on Viticulture and Enology, Yangling, China, 20-22 April 2007; pp. 295-300.

99. Lu, L.; Rahman, I.; Chi, C.G.-Q. Ready to Embrace Genetically Modified Wines? The Role of Knowledge Exposure and Intrinsic Wine Attributes. Cornell Hosp. Q. 2017, 58, 23-38. [CrossRef]

100. Sim, B.; Ryu, K. The Influence of Wine Consumer's Gender on Situational Wine-Drinking Occasions. J. Foodserv. Manag. 2017, 20, 77-98.

101. Nistor, E.; Dobrei, A.G.; Dobrei, A.; Camen, D.; Sala, F.; Prundeanu, $\mathrm{H}_{\text {. }} \mathrm{N}_{2} \mathrm{O}, \mathrm{CO}_{2}$, Production, and C Sequestration in Vineyards: A Review. Water Air Soil Pollut. 2018, 229, 299. [CrossRef]

102. Vendrame, A. When Evidence Is Not Enough: A Case Study on Alcohol Marketing Legislation in Brazil. Addiction 2017, 112, 81-85. [CrossRef]

103. Wine Opinions. Wine Opinions I The Leading Provider of Wine Market Research. Available online: https://wineopinions.com/ (accessed on 5 June 2021).

104. Wine Opinions Wine Market Topics, Trends, and Thoughts. Available online: https://wineopinions.com/wp-content/uploads/ 2020/01/November-2019-Newsletter.pdf (accessed on 5 June 2021).

105. Wine Opinions Wine Market Topics, Trends, and Thoughts. Available online: https://wineopinions.com/wp-content/uploads/ 2020/01/December-2019-Newsletter.pdf (accessed on 5 June 2021).

106. Wine Opinions Wine Market Topics, Trends, and Thoughts. Available online: https://wineopinions.com/wp-content/uploads/ 2020/01/January_2020_newsletter_final4.pdf (accessed on 5 June 2021). 
107. Wine Opinions Wine Market Topics, Trends, and Thoughts. Available online: https://wineopinions.com/wp-content/uploads/ 2020/02/February_2020_newsletter.pdf (accessed on 5 June 2021).

108. Wine Opinions Wine Market Topics, Trends, and Thoughts. Available online: https://wineopinions.com/wp-content/uploads/ 2020/02/March_2020_newsletter.pdf (accessed on 5 June 2021).

109. Wine Opinions Wine Market Topics, Trends, and Thoughts. Available online: https://wineopinions.com/wp-content/uploads/ 2020/04/April_2020_Newsletter_Final2.pdf (accessed on 5 June 2021).

110. Wine Opinions Wine Market Topics, Trends, and Thoughts. Available online: https://wineopinions.com/wp-content/uploads/ 2020/05/Say_Goodbye_to_Gen_Z.pdf (accessed on 5 June 2021).

111. Wine Opinions Wine Market Topics, Trends, and Thoughts. Available online: https://wineopinions.com/wp-content/uploads/ 2020/05/May_Wine_Opinions_Newsletter.pdf (accessed on 5 June 2021).

112. Wine Opinions Focus Groups in the Age of Social Distancing. Available online: https://wineopinions.com/wp-content/uploads/ 2020/06/Discussion_Group_Capabilities_May_2020.pdf (accessed on 5 June 2021).

113. Wine Opinions Wine Market Topics, Trends, and Thoughts. Available online: https://wineopinions.com/wp-content/uploads/ 2020/06/June_2020_Wine_Opinions_Newsletter.pdf (accessed on 5 June 2021).

114. Wine Opinions Wine Market Topics, Trends, and Thoughts. Available online: https://wineopinions.com/wp-content/uploads/ 2020/07/July_2020_Wine_Opinions_Newsletter.pdf (accessed on 5 June 2021).

115. Wine Opinions Wine Market Topics, Trends, and Thoughts. Available online: https://wineopinions.com/wp-content/uploads/ 2020/08/August_2020_Wine_Opinions_Newsletter.pdf (accessed on 5 June 2021).

116. Wine Opinions Wine Market Topics, Trends, and Thoughts. Available online: https://wineopinions.com/wp-content/uploads/ 2020/09/Wine_Opinions_Sept_2020_Newsletter.pdf (accessed on 5 June 2021).

117. Wine Opinions Wine Market Topics, Trends, and Thoughts. Available online: https://wineopinions.com/wp-content/uploads/ 2020/10/Wine_Opinions_Newsletter_October_2020.pdf (accessed on 5 June 2021).

118. Wine Opinions Wine Market Topics, Trends, and Thoughts. Available online: https://wineopinions.com/wp-content/uploads/ 2020/11/November_Wine_Opinions_Newsletter_Final.pdf (accessed on 5 June 2021).

119. Wine Opinions Wine Market Topics, Trends, and Thoughts. Available online: https://wineopinions.com/wp-content/uploads/ 2020/12/December_2020_Wine_Opinions_Newsletter.pdf (accessed on 5 June 2021).

120. Wine Opinions Wine Market Topics, Trends, and Thoughts. Available online: https://wineopinions.com/wp-content/uploads/ 2021/01/January_2021_Newsletter.pdf (accessed on 5 June 2021).

121. Wine Opinions Wine Market Topics, Trends, and Thoughts. Available online: https://wineopinions.com/wp-content/uploads/ 2021/02/February_2021_Wine_Opinions_Newsletter.pdf (accessed on 5 June 2021).

122. Wine Opinions Wine Market Topics, Trends, and Thoughts. Available online: https://wineopinions.com/wp-content/uploads/ 2021/03/March_2021_Wine_Opinions_Newsletter-1.pdf (accessed on 5 June 2021).

123. Wine Opinions Wine Market Topics, Trends, and Thoughts. Available online: https://wineopinions.com/wp-content/uploads/ 2021/04/April_2021_Wine_Opinions_Newsletter.pdf (accessed on 5 June 2021).

124. Wine Opinions Wine Market Topics, Trends, and Thoughts. Available online: https://wineopinions.com/wp-content/uploads/ 2021/05/May_2021_Wine_Opinions_Newsletter.pdf (accessed on 5 June 2021). 